\title{
Linking Conservation, Community Knowledge, and Adaptation to Extreme Climatic Events: A Case Study in Gorongosa National Park, Mozambique
}

\author{
Amemarlita Matos ${ }^{1}$, Laura Barraza ${ }^{2, *}$ and Isabel Ruiz-Mallén ${ }^{3}$ (D) \\ 1 Department of Human Development, Gorongosa National Park, Beira 1983, Mozambique; \\ amemarlitamatos@yahoo.com.br \\ 2 Education for Sustainability, SACBÉ-Servicios Ambientales, Conservación Biológica y Educación A.C. \\ de México, Mexico City 04100, Mexico \\ 3 Internet Interdisciplinary Institute (IN3), Univesritat Oberta de Catalunya, 08860 Barcelona, Spain; \\ iruiz_mallen@uoc.edu \\ * Correspondence: laubarraza@gmail.com
}

\section{check for}

updates

Citation: Matos, A.; Barraza, L.; Ruiz-Mallén, I. Linking Conservation, Community Knowledge, and Adaptation to Extreme Climatic Events: A Case Study in Gorongosa National Park, Mozambique. Sustainability 2021, 13, 6478. https:// doi.org/10.3390/su13116478

Academic Editors:

Bernardo Hernandez and Ernesto Suarez

Received: 19 April 2021

Accepted: 3 June 2021

Published: 7 June 2021

Publisher's Note: MDPI stays neutral with regard to jurisdictional claims in published maps and institutional affiliations.

Copyright: (c) 2021 by the authors. Licensee MDPI, Basel, Switzerland. This article is an open access article distributed under the terms and conditions of the Creative Commons Attribution (CC BY) license (https:// creativecommons.org/licenses/by/ $4.0 /)$.
Abstract: This study is based on ethnographic research that analyzes how traditional knowledge and local beliefs on biodiversity conservation relates to the local ability to adapt and be resilient to climatic changes in two communities around Gorongosa National Park, Mozambique: Nhanfisse in the buffer zone and Muanandimae in the core area. A total of 78 semi-structured interviews with heads of households were conducted. We found that both communities carried out practices and held beliefs associated with conservation, such as protecting trees and animal species considered sacred or perceived as beneficial for human life in terms of water provision and agricultural production. In addition to traditional ceremonies that respond to extreme climatic events such as drought and flood, other adaptation strategies used by the communities include moving to neighboring areas in search of better living conditions and using forest products in times of scarcity. We discuss that the management of the park should be agreed on, in a shared way, between local communities and conservation agents to ensure that these areas continue to perform the ecological, subsistence, and spiritual functions required. Our research results contribute to a better understanding of local adaptation dynamics towards extreme climatic events and improvement of management strategies.

Keywords: social-ecological memory; traditional ecological knowledge; protected areas; adaptive management; climate change

\section{Introduction}

Human beings are considered agents of change within ecosystems, which is why the functioning of social-ecological systems does not depend exclusively on natural environmental conditions, but also on the diversity of local cultural values and practices [1,2]. Cultural traditions constitute a core part in the social structure of communities. That is how local culture, belief, and practices have been adapted and shaped in response to human needs, so they can help explain human-nature and nature-culture interactions [3]. In this process, traditional ecological knowledge and socio-ecological memory provide information on historical land use practices, explain various socio-environmental phenomena, and provide mechanisms to respond to environmental changes, which can facilitate crisis responses and contribute to maintaining the resilience capacity of socio-ecological systems over time [4-7].

Traditional ecological knowledge (TEK) is a set of an accumulative body of knowledge, practices, and beliefs, that have evolved through adaptive processes and have been passed down through cultural transmission generations, about the relationship between living beings (including humans) and the environment [8]. Socio-ecological memory, in turn, describes how an individual thought, originated from a given experience, can become part 
of the collective knowledge of a group of people or communities [9]. Memory is used by humans in their daily lives. This collective set of memories provides the individual with the ability to deal with routine events and respond positively to new events, thus ensuring socio-ecological resilience [9]. TEK and socio-ecological memory are incorporated into communities by means of local languages, cultural values, beliefs, rituals, community laws, religious beliefs, taboos, customs, innovations, and other cultural practices [10]. Regularly, such bodies of knowledge are transmitted orally from generation to generation, usually in the form of stories, songs, folklore, and proverbs, in addition to direct training of young people by their elders $[7,11]$. This knowledge is an integral part of a community's identity and forms the basis of the community's livelihoods, connecting people to their land and natural resources [12].

This body of knowledge is part of a complex system that is not isolated from the social and institutional structures of a community. According to Hanna et al. [13], the structures and dynamics of the institutions are critical for the implementation of management practices based on social-ecological understanding in any society. Therefore, as we explore and learn more about the ecological knowledge and the socio-ecological memory of human communities, we can better understand the dynamics of the interrelationship between the ecosystem and the communities themselves in the face of climatic and environmental events. Within social systems, socio-ecological memory ensures that the knowledge, experience, and practice of how to manage an ecosystem and its services that are retained and stored among a group of people, is modified and transmitted over time, thus guaranteeing information sharing by community members [11]. Therefore, the importance of knowing the traditional practices of natural resource management those communities maintain as part of their culture and identity.

In this vein, TEK is a key factor shaping communities' adaptive capacity and socialecological systems resilience, as it has been shown in community-based conservation contexts [14]. In areas where there is a strong human influence, whether negative or positive for natural resources, due to the high dependence on natural resources for their survival, the implementation of biodiversity conservation strategies must be done taking into account the historical relationship between the human community and natural resources as a way to avoid conflicts with local communities [15]. When planning or implementing protected areas, the capacity for adaptation and resilience of these traditional systems must be taken into account, since the ecological and social resilience is linked through the existing dependence and connection of human beings and ecosystems [16].

In Africa, Mozambique is one of the country's most prone to climate change (tropical cyclones, floods, and droughts), due to its geographical position along the intertropical convergence zone responsible for rainfall patterns in Southern Africa [17]. In recent years, drought, flood, and cyclone occur with greater frequency and intensity, which has a cumulative and devastating impact on the population that is not sufficiently prepared [18-22]. Furthermore, in Mozambique there are few studies registered on TEK from communities surrounding the protected areas. Most of the studies found are on the effects that some natural resources have on the life of rural communities in Mozambique [23-25]. However, not one specific study, to the best our knowledge, analyzes TEK in relation to local adaptation strategies to climatic events. To fill this gap, this study provides new evidence in this regard through a research conducted in the Gorongosa National Park (GNP). On the one hand, it brings us closer to knowing local communities' traditional knowledge about aspects of conservation and how such body of knowledge relates to its ability to be resilient to these climatic changes. On the other hand, it identifies what adaptation strategies they have developed towards extreme climatic events.

Taking into account the roles that traditional knowledge and socio-ecological memory play in local communities, the aim of this study is to identify the adaptation strategies that two communities around the GNP have to deal with extreme climatic events. This includes finding out how TEK can shape different aspects of conservation and help communities be 
resilient to these changes, while exploring the practices, beliefs, and traditional knowledge of the communities that are linked with the conservation of biodiversity.

Gorongosa National Park (GNP) is a protected area which has about 200,000 people living in its buffer zone [26]. GNP is under restoration after losing $90 \%$ of its population of large and medium-sized mammals due to the effects of the Civil War of 16 Years [26,27]. However, the restoration project is not only focused on the recovery of biodiversity, but also on socio-economic development and the active participation of local communities in biodiversity conservation strategies [26]. The GNP is an interesting and valuable case study since its geographical location makes it vulnerable to various climatic events, with floods, droughts, cyclones, tropical depressions in the Indian Ocean and cold southern fronts being the most frequent events $[28,29]$. Therefore, it is important to know the adaptation strategies in the face of recurring events (such as drought and flood) used by local communities, as well as the factors that guarantee and govern their resilience, as a way to guarantee the sustainability of GNP and local communities. Since the link between communities residing in GNP and natural resources, plays an important role in resilience and adaptation to climatic events for the whole community.

\section{Local Ecological Knowledge and Climate Adaptation in Protected Areas}

Climate change is impacting global and social systems bringing fundamental changes to human behavior, particularly in vulnerable groups, in economically developing communities [30]. Therefore, it is increasingly urgent that such communities possess the capacity to respond to climate change now and in the future [31]. In this sense, many local communities hold knowledge related to the functioning of ecosystems, sequences of natural events, and responses to extreme events [32]. The diversity of TEK related to responses to environmental changes is related to lived experiences and knowledge transmitted over generations [4,5]. TEK can influence responses to sudden or recurring events, such as severe floods and droughts, thus ensuring a greater and more efficient reaction to these events [5]. An example of this is illustrated in the case of Doñana National Park in southern Spain, where communities around the park use TEK to respond to recurring and severe drought events, which facilitate collective responses and prevent the occurrence of social conflicts [5]. The TEK that communities have about the management of their resources and their high level of social resilience to adapt to changes has allowed these communities to survive in conditions that are often unimaginable. Studies have demonstrated that communities who are more in touch with their surroundings are able to accurately detect environmental changes such as seasonal temperature and weather fluctuations [33-35].

However, in the context of government-led protected areas, such as national parks, we need to work on conservation and adaptation strategies that support how communities cope with unexpected, dramatic, and devastating weather events in order to create better living conditions while protecting biodiversity. Knowing the local traditions of the communities living around national parks, their natural resource management practices and their responses to extreme recurring events, will allow us to understand the interrelationships that exist between people and their resources, helping establish connections between social and natural phenomena. In this way, we can establish conservation management policies respecting the environmental values of local communities and guarantee the conservation of biodiversity and its socio-ecological resilience. The incorporation of TEK from communities living close to the protected areas can be a powerful tool to enhance the inclusion of local communities in decision-making processes, as well as their active participation in biodiversity conservation $[4,36]$.

\section{Materials and Methods}

Gorongosa National Park (GNP) in Mozambique is located at the southern end of the Great Rift Valley, East Africa, in a region of high species diversity with ecological features found nowhere else on Earth (Figure 1). The core area of the GNP, together with its buffer zone, occupy an area of about $10,000 \mathrm{~km}^{2}$ [26,37]. Two communities were 
selected for this study to analyze whether the location and conservation policies of the park are factors shaping the conservation and adaptation practices traditionally developed by these communities. Muanadimae is located inside the GNP and Nhanfisse is located in the buffer zone (Figure 1). Both communities are situated in open and closed forests that have a variety of precious trees species, namely: Pau-preto (Dalbergia melanoxylon), sandalo (Spirostachys africana); 1st Class wood: Umbila (Pterocarpus angolenses), panga panga (Millettia stuhlmannii), chanfuta (Afzelia quanzensis), African mahogany (Khaya nyasica); 2nd Class Wood: Missasa (Brachystegia spiciformis), Metonha (Sterculia quinqueloba) [38,39].

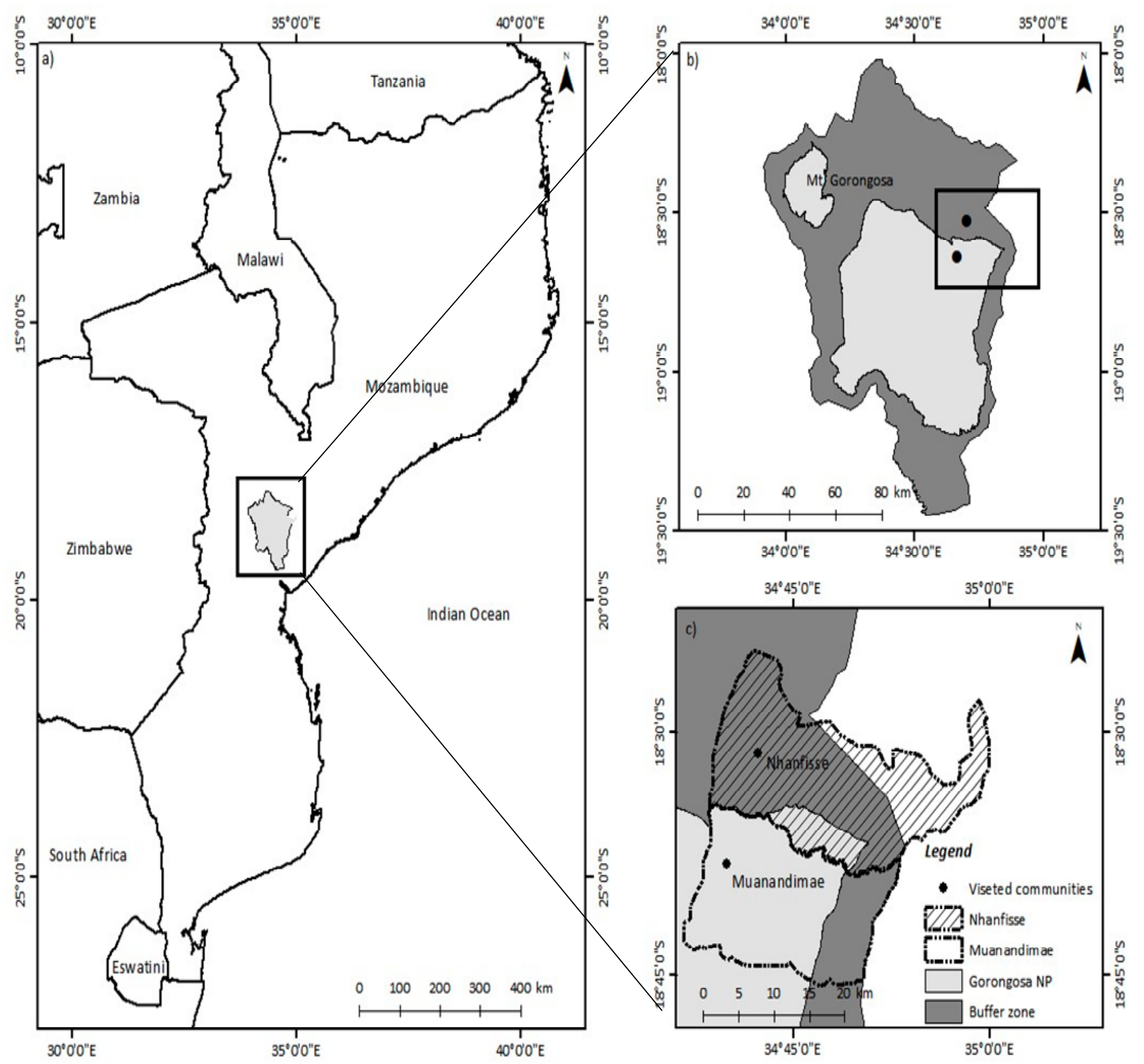

Figure 1. Location of study area (source: Scientific Department Gorongosa National Park).

Muanandimae has an estimated population of 618 inhabitants, representing 225 households [38]. In addition to the native population, some members of this community come from neighboring communities such as Maringue, Chemba, Caia, Gorongosa, and Muanza. Since this community is located in the core area of the GNP, the restriction in the use of natural resources is strict, mainly in the opening of new areas for cultivation as well as in the control of poaching, felling of trees, and uncontrolled fires. In this community, access to drinking water is still poor, communities obtain water from traditional wells that are open inside the close Nhanfisse River [38].

Nhanfisse is located in the buffer zone of the park and borders with the territory of Muanandimae community. Nhanfisse has an estimated population of 865 inhabitants, 
representing 173 households. Due to the high fertility of the soils as well as the Civil War of 16 years, the community of Nhanfisse has received immigrants from neighboring communities, Maringue, Chemba, Caia, Gorongosa, Muanza, and Dondo, thus presenting a growth of its population [39].

In both communities, participants practice poultry and goat farming as some activities they do for subsistence, however, agriculture and the use of forest products are the main source of subsistence (Table 1). Both communities are dedicated to the cultivation of corn (Zea mays) and sorghum (Sorghum sp) for family consumption and sesame (Sesamum indicum) and pigeon pea (Cajanus cajan) for commercial crops [38,39]. Interventionary studies involving animals or humans, and other studies that require ethical approval, must list the authority that provided approval and the corresponding ethical approval code.

Table 1. Activities practiced by the communities (source: Interview responses).

\begin{tabular}{ccc}
\hline Activities & Muanandimae & Nhanfisse \\
\hline Agriculture & $35(100 \%)$ & $42(97.67 \%)$ \\
Recollection & $30(85.71 \%)$ & $38(88.37 \%)$ \\
Poultry farming & $30(85.71 \%)$ & $38(88.37 \%)$ \\
Caprine & $6(17,14 \%)$ & $8(18.60 \%)$ \\
Business & $1(2.86 \%)$ & $5(11.63 \%)$ \\
Formal job & $0(0 \%)$ & $2(4.65 \%)$ \\
Total respondents & $35(100 \%)$ & $43(100 \%)$ \\
\hline
\end{tabular}

\subsection{Data Collection}

This ethnographic research study was carried out between October and November 2018 through qualitative methods. A total of 78 semi-structured interviews with heads of households (men and women over the age of 18) were conducted: 35 in the community of Muanandimae and 43 in Nhanfisse. The sample size was determined by the saturation point in the responses, which is defined as the point at which new information will not be obtained through an additional interview. That is, when additional data do not provide new ideas, but confirm previous theories, since the most important ideas for formulating a theory or facts in the community have all been obtained $[40,41]$.

Semi-structured interviews asked about two topics: "Are the practices, beliefs and traditional knowledge of the communities linked with the conservation of biodiversity? and "What are the adaptation strategies communities have to deal with extreme climatic events?". Questions were asked in the local language (i.e., Sena) by the first author who was helped by a local male translator in the community of Nhanfisse, and a female translator in the community of Muanandimae. Both translators did not belong or held any position in the community, as a way of not influencing the interviewees' responses. The local translators were also able to ask follow-up questions if they thought they could obtain additional relevant information. The interview guide was tested in a neighboring community with characteristics identical to the study area, which is about $20 \mathrm{~km}$ away.

With the authorization of the interviewees, all the interviews were recorded, and observations of the contextual details such as the fruits, food, and species consumed, the body expression of the interviewees, and the surroundings were noted in field notebooks in order to be able to confront with the information given by the interviewees. The interviews lasted between 30 to $60 \mathrm{~min}$, depending on the interviewee's desire and experience. Some interviews were interrupted when fatigue, lack of concentration or unwillingness was observed.

\subsection{Data Analysis}

Data from the interviews and field observations were analyzed qualitatively through the conventional content analysis. Each interview was transcribed and using content analysis, we quantified and analyzed the presence, meanings, and relationships of certain words, themes or concepts described by each interviewee. The analysis codes were assigned 
to the contents of the interviews in which patterns and themes found in the interviews were related. Then, specific categories were created: Knowledge on plant names (theoretical knowledge), knowledge on plant uses (practical knowledge), beliefs about the forest, and knowledge about customary restrictions related to conservation. These categories or codes were quantified to know how many informants had mentioned them. The Nvivo 12 Plus program was used to assist in this analysis.

The main local practices and beliefs related to biodiversity conservation and the traditional knowledge that community members have influencing biodiversity conservation processes were identified. For this, we used word cloud as a visual analysis tool to identify the most important aspects that were pointed out by the interviewees in different topics of the study. For example, for the identification of "sacred sites", we identified all the words in the interviews associated with this topic, then we create the nod under the name "sacred sites", and all phrases or words that were related to the sacred sites were marked as important and dragged to the respective node.

To assess the ability to adapt and respond to recurring events, we used the classification on the adaptation processes suggested by Thornton and Manasfi [42]: Mobility, exchange, rationing, pooling, diversification, intensification, innovation, and revitalization. In this study, we considered six processes according to the identified adaptive practices developed by the communities to respond to the stress caused by a disturbance (e.g., dry or flood) (Table 2).

Table 2. Adaptation processes: Overview.

\begin{tabular}{|c|c|c|}
\hline \multicolumn{2}{|c|}{ Adaptation Process } & \multirow{2}{*}{$\begin{array}{l}\text { Description } \\
\text { Seasonal movement or permanent migration to avoid risk or in } \\
\text { search of better circumstances. }\end{array}$} \\
\hline 1. & Mobility & \\
\hline 2. & Exchange & Flow of material and symbolic goods and services between people. \\
\hline 3. & Pooling & $\begin{array}{l}\text { Sharing or linking of assets (wealth, labor, knowledge) across } \\
\text { social groups. }\end{array}$ \\
\hline 4 . & Diversification & $\begin{array}{l}\text { Increasing the variety of food, income production strategies, } \\
\text { specialization, etc., to enhance livelihoods. }\end{array}$ \\
\hline 5. & Intensification & $\begin{array}{l}\text { Increasing the availability of resources by boosting their yield within } \\
\text { a certain space or time. }\end{array}$ \\
\hline 6. & Revitalization & $\begin{array}{l}\text { Organized reconfiguration of ideology and practices to reduce stress } \\
\text { and create a more satisfying culture. }\end{array}$ \\
\hline
\end{tabular}

We also collected data on the households' main subsistence activities which were analyzed quantitatively through percentages of relative frequencies. For the construction of graphs, this study used the GraphPad Prism 5 program [43].

\section{Results}

\subsection{Traditional Knowledge, Beliefs, and Practices towards Biodiversity Conservation}

We found that in both communities, the interviewees carry out practices and hold beliefs associated with conservation. These conservation-related practices and beliefs mainly involve the protection of trees, as well as some animal species considered sacred or perceived as beneficial for human life in terms of water provision and agricultural production. However, in terms also of supporting and maintaining ecosystems and climate regulation. For instance, one of the informants explained why not cutting big trees is beneficial, since they are considered as trees that guarantee the non-erosion of soils on the river banks as well as rainfall and protected the riverbed.

The results show that a large part of the interviewees $(68.6 \%$ of respondents from Muanandimae and $55.8 \%$ from Nhanfisse) responded that in the past (before the protected 
area and its conservation regulations) there were already customary restrictions and rules for the use of trees. "Do not cut trees" was the phrase most used by the interviewed residents in relation to the management of natural resources made in the past by the communities of Muanandimae (inside the GNP) and Nhanfisse (BZ of GNP) (Figure 2).

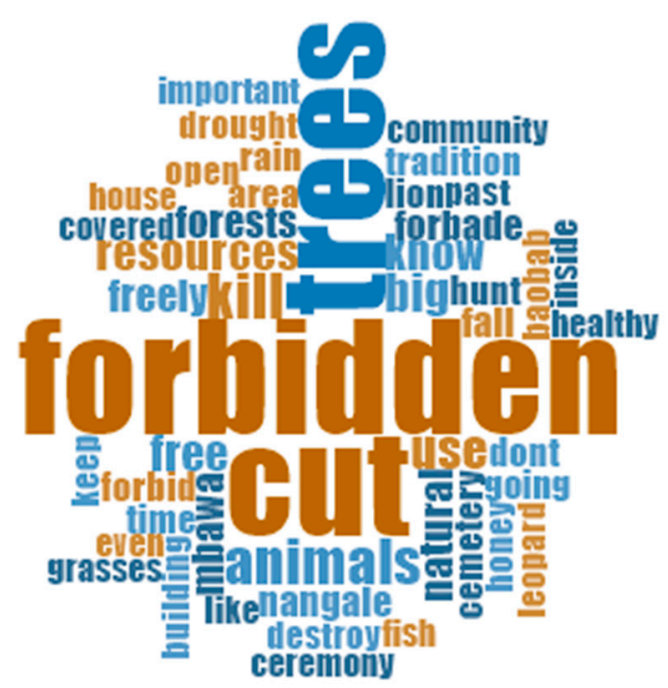

Figure 2. Use of natural resources in the past by the communities.

As explained by the 90-year-old Muanandimae régulo (chief of the community), "cutting down the following trees species was prohibited: Mbawa (Khaya nyasica), Mulambe (Adansonia digitata), Munangale (Combretum imberbe), Mussacossa (Afzelia quanzensis), Ndjale (Sterculia appendiculata) and Muanga (Pterocarpus angolensis), as well as those adult trees and trees near rivers because they were considered as trees that guaranteed the non-erosion of soils on the banks of rivers and protected the riverbed as well as were necessary for rainfall". In this last regard, most of the interviewees from Muanandimae $(76.2 \%)$ and Nhanfisse $(60 \%)$ emphasized that the trees are reserved to guarantee the rain conservation.

Another 32-year-old interviewee from the Muanandimae community said "in the past we could open fields, and cut down trees. Regulo said not to cut: Mbawa (Khaya nyasica), Munangale (Combretum imberbe), Mussacossa (Afzelia quanzensis), Ndjale (Sterculia appendiculata), because they are trees that help. Because it is from these trees that rain comes. If you cut, the rain will not fall. But we could hunt freely".

In the past, the places for agricultural practice as well as for housing construction were guided by the régulo. When asked how the use of natural resources is currently regulated, the respondents from the community that resides inside the park (Muanandimae), replied that the restriction is now absolute and that the rules come from Gorongosa National Park (GNP). However, for the community living in the buffer zone (Nhanfisse) the situation is different, the cutting of trees is controlled, but they are allowed to open areas for cultivation. Although, hunting is entirely prohibited by GNP.

Regarding the restrictions on the use of trees, we found that a high percentage of informants reported that most of the trees remain intact to ensure there is more rain $(85.7 \%$ Muanandimae and $73.3 \%$ Nhanfisse). Only about $17 \%$ of the interviewees use trees for wood (20\% in Nhanfisse and 14.29\% in Muanandimae). Moreover, $20 \%$ of the Nhanfisse informants use trees for ceremonies and/or traditions and to a lesser extent participants from Muanandimae, with $9.5 \%$.

Regarding sacred sites, we found that participants from both communities highlighted cemeteries and certain forest areas as the two most important sacred sites. They mentioned that in these places no activity is allowed since spaces are reserved for spirits. Interestingly, only $8.6 \%$ of the interviewees identified the presence of a sacred forest in the community of Muanandimae, and usually these were forest areas containing sacred trees, that they could 
not cut. While all local residents in this community shared this belief, only $5.6 \%$ identified forests as sacred sites. In the same vein, in the community of Nhanfisse, only native residents identified a lagoon as a sacred place $(4.7 \%)$, while for immigrants it was not.

Finally, regarding wildlife, only 2.9\% (Muanandimae) and 2.3\% (Nhanfisse) referred to customary rules aimed at not killing large animals such as elephants, (Loxodonta africana), buffalos (Syncerus caffer), zebras (Equus burchelli), lions (Phantera leo), and leopards (Phantera pardus). A 31-year-old interviewee from the Muanandimae community said that "we could not kill Buffalo, lion, elephant, because they are big animals and they value our life. We could only kill small animals". As for which animals were considered sacred, for both communities the lion was uniquely named as a sacred animal by $60 \%$ and $55 \%$ of respondents from the community of Muanandimae and Nhanfisse, respectively. The main reason given by interviewees from both communities was that the lion represents the sacred spirit of the régulos (chiefs) when they die. There was no mention of any other animal considered sacred in the Nhanfisse community, but in the Muanandimae community 11.6\% mentioned leopard, pangolim, hyena, and aardvark as sacred animals, since they are hard to see.

\subsection{Community Adaptation Processes and Strategies Used to Respond to Recurring Events}

We found that interviewees from the two communities reported adaptation strategies to deal with climatic changes they perceive. In Muanandimae $85.7 \%$ of respondents and in Nhanfisse $88.4 \%$ perceived changes in the climate over time, arguing that it now rains much less than before, that rain does not follow the same temporal patterns than before, and that in general it is getting warmer. This information is related and stored in their socio-ecological memory as part of the collective knowledge shared by members of the communities. Therefore, their perception of this phenomenon is related to their day-today experience, especially with regards to the increase in temperature, as they compare current temperatures with those of the past. Some interviewees related such perceived climate variability with cutting trees down and disregard for traditional natural resource use practices such as open land for agriculture, but most of them were unable to provide an explanation on the causes that produce these climatic changes (Table 3).

Table 3. Interviewees' perception of the causes of weather changes.

\begin{tabular}{ccc}
\hline Causes of Weather Changes & Muanandimae (\%) & Nhanfisse (\%) \\
\hline Do not Know & 64.5 & 50 \\
Cutting trees down & 6.5 & 21.1 \\
Disregard for traditional natural resource use practices & 12.9 & 10.5 \\
God knows & 0 & 10.5 \\
No answer & 16.1 & 5.3 \\
Climate change & 0 & 2.6 \\
\hline
\end{tabular}

It is notable that for the community that lives outside the park, Nhanfisse, the response to the changes in the climate was strongly associated with God by saying that "he is the only one who knows why these changes occur". According to field observations, religion is usually an important aspect for the communities around the park and it has a strong influence on shaping and even abandoning the traditions and customs of the communities. Despite that fact, and in view of the recurring events such as the droughts that affect this area, in both communities' traditional ceremonies were still mostly held in cases of delay of rainfall. The traditional ceremony related to the delay of rainfall was the most frequently answered by the participants in both communities, as shown by the word cloud (Figure 3). For the rain ceremony, community members make small contributions related to food products such as corn flour and sorghum. The traditional ceremony is held by the local chief and is attended by all members of the community. These ceremonies are usually held near the house of the régulo (chief), who is the one that preceded it, in the ceremony, he asks the spirits to bring the rain for the harvests. 


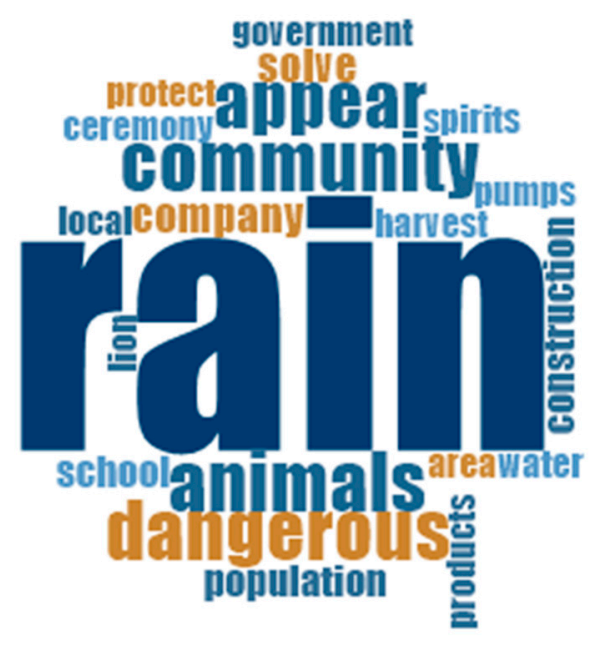

Figure 3. The most important ceremony.

In addition to traditional ceremonies, to respond to extreme climatic events such as drought and flood, the main adaptation strategies used by the communities of Nhanfisse and Muanandimae are shown in Table 4. As a way of responding to food shortages due to drought and flood, the interviewees showed that they would move to neighboring areas in search of better living conditions. Both respondents who showed mobility as well as those who prefer not to move temporarily identified the use of forest products to respond to times of scarcity.

Table 4. Interviewees' perception of the causes of weather changes.

\begin{tabular}{cl}
\hline Adaptation Process & \multicolumn{1}{c}{ Description } \\
\hline Mobility & $\begin{array}{l}\text { Temporary movements during the dry season to carry out temporary work, movement to high areas } \\
\text { during floods, movement to wet areas during the dry season, movement to safe areas during the war } \\
\text { as well as movement to fertile areas for farming. }\end{array}$ \\
\hline Exchange & In times of crisis, they share food products among community members (family, friends, neighbors). \\
\hline Pooling & $\begin{array}{l}\text { When faced with food shortages, respondents consume: Dioscorea Sp, Cordyla Africana, Bobgunnia } \\
\text { madagascariensis, Gloriosa superba, Bridelia micrantha, Sclerocarya birrea, Adansonia digitata, Strychnos } \\
\text { spinosa, Tamarindus indica, honney, Hyphaene coriácea, Trichilia emetic, Deinbollia xanthocarpa, Ximenia sp, } \\
\text { Nymphaea nouchali, Piliostigma thonningii, banana root, wild fruits. }\end{array}$ \\
\hline Diversification & $\begin{array}{l}\text { Agriculture, use of forest products, poultry, goat, and swine. Poultry, goat, and pig farming helps } \\
\text { them not only during times of scarcity but also in the diversification of their diet. }\end{array}$ \\
\hline Intensification & $\begin{array}{l}\text { In order to guarantee food during the dry season, respondents cultivate in areas close to the river due } \\
\text { to its fertility and soil moisture. }\end{array}$ \\
\hline Revitalization & $\begin{array}{l}\text { When faced with a crisis situation, the practice of temporary jobs and consumption of forest products } \\
\text { are some of the strategies used by the interviewees. Particularly in the case of the delay of rainfall, } \\
\text { the practice of traditional ceremonies asking for rain is common. }\end{array}$ \\
\hline
\end{tabular}

As explained by many interviewees, the strategies used by communities to respond to drought and flood events are based on their past experiences of those events, for example, they mentioned that in times of crisis, they share food products among community members (family, friends, and neighbors). Their responses allow them to successfully develop a strategy to respond to environmental extreme events.

Forests were seen as the place to obtain part of their daily needs, ranging from stakes for the construction of houses, firewood, and wild fruits, as well as the places for storage when faced with lack of food due to recurring events such as dry or rainy weather. 


\section{Discussion}

Findings show that in both communities, their traditional norms and customs seem to have helped them conserve some species, mainly trees, even before the creation of the national park. This can be linked to the TEK that these communities have on some tree species recognized as beneficial in climate regulation and important for rainfall. TEK can favor conservation as long as there is a support process for the communities [44]. In other words, supporting policies are needed in conservation and management processes to assist the actions that best favor the communities' wellbeing and the protection of nature. Conservation goals need to coincide with the practices and perspectives on rights to resource use in the TEK-holding communities. These results concur with other studies showing that forests have been protected by indigenous knowledge beliefs, where taboos forbade people from entering them and some trees were declared sacred and forbidden to cut down, which made them remain untouched for generations [45]. Studies by Fongod et al. [46] in the South and Southwest of Cameroon also show how traditions, customs, beliefs, and cultural rights have played an important role in the conservation of biodiversity in this region [46]. In rural communities from other developing countries, such as Suriname, it is believed that, if nature is not respected, the balance will be lost and there may be spiritual sanctions in the form of illness, accidents or misfortunes [47].

We also found that for the members of the two communities, cemeteries are places that represent respect not only for the people who were buried there, but also for the trees, water access, and all types of vegetation found there. For these communities, cemeteries are considered sacred in which certain species of trees have been protected. Cemeteries then, can be conservation islands for the protection of animal and plant species. It is not surprising to find that in other African countries, cemeteries also represent sacred places for conservation. Similar to studies in Ghana that show that cemeteries are considered to be the home of ancestors and thus they must be kept pure. Hence, the exploitation of resources through activities such as agriculture, hunting, and cutting trees is prohibited until certain rituals are performed [48]. Cemeteries play an important role in the conservation of certain organisms, as they often serve as refugees for rare and threatened species due to the protection laws that these places have on part of the communities [49]. Beyond cemeteries, there are other sacred areas playing an important role in conservation, as we also found in the case of forested sites. In Mozambique, the Chimanimani National Reserve has sacred areas reserved for invoking ancestral rituals, where their access and the use of the resources are prohibited [50]. However, studies show that the existence of sacred forests or sacred trees is no guarantee that biodiversity will be preserved for a long time, especially if this knowledge is not transmitted over generations and with the influence of population growth these areas end up being degraded by anthropogenic activities [51].

Our findings also show that only a small proportion of respondents from Muanandimae and Nhanfisse identified the existence of a sacred forest or a pond with sacred value, respectively, with most of them being native to the place and communities. An explanation for this may be due to the traditional knowledge and socio-ecological memory of the place to which one belongs, since there is a sense of belonging and cultural identity to the place of origin linked to the maintenance of such local and customary body of knowledge [10]. Another explanation can be that there are gaps in the process of transferring knowledge from the elderly to the young, as well as to community members from neighboring regions [52]. The loss of TEK is directly linked to external migration, as local people who move away from their area inevitably carry important knowledge about land use [53]. Traditional knowledge and socio-ecological memory are transmitted orally from generation to generation, the existence of gaps during the process of knowledge transfer due to migration are quite common $[7,11,12]$.

Regarding our second question, what are the adaptation strategies that these communities have to deal with extreme climatic events, our findings suggest that local communities perceive these changes and have developed adaptation strategies through relying on their socio-ecological memory and traditional knowledge when faced with periods of drought 
and severe flood. Responses of the interviewees suggest an increase in temperature and unpredictable rainfall, as well as a reduction in annual precipitation. They perceive these changes in relation to the agricultural cycles of their crops. Among the possible causes that local informants mentioned during the interviews, it is pertinent to discuss the reasons why some members of the community that live around the park (Nhanfisse) pointed out that deforestation is a cause that may be affecting these changes in the climate. Interestingly, for those living inside the park (Muanandimae), only a few associated cutting down trees with perceived climatic changes. This may be due to the fact that the community that lives inside the park does not directly see deforestation practices, since they live within a protected area where this practice is prohibited, and yet they see year after year how the temperature changes and affects their crops. Contrary to this, for the community that lives in the margins of the park, deforestation is a daily practice to which they are exposed and see every day. Therefore, some of them relate such direct, experienced forest destruction with observed climatic changes. Similar results were found in Tharaka eastern Kenya, where community members closely linked climate change and temperature variability to environmental degradation, ocean pollution, the use of pesticides, and insecticides [54].

In order to respond to severe drought events, our findings show that traditional ceremonies are held in both communities. These results are in line with research that shows that many African communities practice traditional ceremonies as a means of survival during extreme weather events and other natural hazards, and this practice has the potential to facilitate the most effective responses to climate change [55]. For South Africa, rain ritual ceremonies between African communities and Vatsonga are carried out with the aim of influencing the climate during periods of drought to allow rain to fall for the benefit of humans and animals [56]. Such local belief system helps maintain socio-ecological resilience, creating social cohesion during crises [5].

The results also suggest that the high mobility that respondents from the Muanandimae and Nhanfisse have, serves as a means of responding to food shortages caused by drought and flood. For these communities, the migration that household heads adopt during times of scarcity to areas that have good productivity, plays an important role in the survival of these families, also since it helps respond peacefully. Mobility has been very common for people living in semiarid regions as a mechanism used to deal with variations in space and time in precipitation and productivity [57]. According to Adger (2000), circular and seasonal migration are important aspects for social stability. In many parts of the world, farmers have undergone seasonal migration in response to climate change and this contributes to household subsistence security and resilience. Similar results to those found in this study were also found in Humla, where farmers in this community used seasonal migration as a means of subsistence and a strategy for diversifying sources of subsistence [58].

We believe that some adaptation strategies used in both communities favor resilience in the face of climate change as these communities have been adjusting their lifestyles in response to extreme weather events. They have shown coping strategies among themselves in the event of climate crisis, including the use of bonding, borrowing, and reciprocity, as well as migration and reduction in food consumption. However, other strategies such as migration can be seen as maladaptive practices in terms of biodiversity conservation due to the associated loss of TEK. It is important, therefore, for GNP and government agencies to understand how these communities respond to climate change and how their efforts can be improved within a framework of resilience thinking.

Moreover, we think that TEK can shape different aspects of conservation and help them be resilient to these changes. As we mentioned earlier, TEK is an integrated system of knowledge, practice, and beliefs and these beliefs, values, and traditions have helped these communities conserve important tree species and animals for their ecosystem.

Despite the TEK and the adaptation strategies to climatic risks that these communities have, they are still highly dependent on agriculture and forest resources. Similar results were observed by the communities of the Limpopo National Park, which when faced 
with drought, they resorted to wild fruits and plants that reduce appetite as a way to face the crisis [59]. As in southern Madagascar, the Tandroy people resorted to the use of wild berries when faced with severe drought [60]. However, it will be necessary to question whether highly dependent systems on agriculture favor sustainable life processes? Land, water, and forests are the primary resources of agricultural production, and are the resources essential to maintain human life and well-being. Though, the high dependence on restricted resources, such as forest products, can negatively influence the social resilience of these communities [16]. High dependency reduces the flexibility with which the resource user can easily adapt to changes [61,62]. Moreover, for communities highly dependent on natural resources living within or around protected areas, restricting or banning the use of natural resources directly affects their way of life and will make them vulnerable to both extreme events and their economy [63]. The creation of a protected area brings with it new policies, such as restricting the use of natural resources and increasing the protection and conservation of natural resources existing in these areas [4]. Natural resource users who are economically dependent on these resources can be more vulnerable to these institutional changes since they lack the skills and attitudes necessary to successfully cope with a period of changing usage policies [61].

\section{Conclusions}

Our study highlights the socio-environmental value of working with communities that live inside and outside the GNP in order to better understand the dynamics of the relationship between the communities' wellbeing and the conservation goals of the park. Knowing the adaptation strategies that communities have to face climate change in national parks and other protected areas will allow us to understand the interrelationships that exist between people and their resources and how conservation rules shape them, helping to establish connections between social and natural phenomena. In this way, we can establish conservation management policies respecting the environmental values of local communities and guarantee the conservation of biodiversity and its socio-ecological resilience. Therefore, GNP in partnership with local communities must create conditions for diversifying the livelihoods of local communities and thus, reduce dependence on certain natural resources to guarantee their conservation. In addition, the management of sacred areas and wildlife within the park should be agreed on, in a shared way, between local communities and conservation agents to ensure that these areas continue to perform the ecological, subsistence, and spiritual functions required. This is a strong reason why conservation policies should be created to support the safety of these communities and help remedy times of environmental crisis.

The incorporation of TEK from communities living close to the protected areas can be a powerful tool to enhance the inclusion of local communities in decision-making processes, as well as their active participation in biodiversity conservation.

The originality of this article lies in the fact that this study is the first of its kind in Mozambique that analyzes TEK in relation to local adaptation strategies to climatic events in communities living around natural protected areas. This study provides new evidence bringing us closer to knowing local communities' traditional knowledge about aspects of conservation and how such body of knowledge relates to its ability to be resilient to these climatic changes and knowing what adaptation strategies they have developed towards extreme climatic events.

Some of the research limitations in this study were access to communities due to the cyclone Idai and having to rely on translators for the local language.

Author Contributions: Conceptualization, L.B. and A.M.; methodology, L.B. and A.M.; validation, I.R.-M. and L.B.; formal analysis, A.M.; investigation, A.M. and L.B.; resources, L.B. and I.R.-M.; data curation, A.M., L.B., and I.R.-M.; writing-original draft preparation, L.B. and A.M.; writing-review and editing, L.B. and I.R.-M. All authors have read and agreed to the published version of the manuscript. 
Funding: This project was funded by the Howard Hughes Medical Institute, grant number 54108287. I.R-M. acknowledges support from the Spanish State Research Agency through a "Ramón y Cajal" research fellowship (RYC-2015-17676).

Institutional Review Board Statement: The study was conducted according to the guidelines of the Declaration of Helsinki, and approved by the Scientific Department of Gorongosa National Park on 18 August 2018.

Informed Consent Statement: Informed consent was obtained from all subjects involved in the study.

Data Availability Statement: Data supporting reported results can be found at the Scientific Department of Gorongosa National Park.

Acknowledgments: Our deepest gratitude to the people of the two communities, Muandandimae and Nhanfisse, that participated in this study. We would also like to thank the Gorongosa National Park staff who assisted with project logistics, especially Hercilia Chipanga, Jantar Piano, and Berta Guambe. We are grateful to Celina Diaz and Samuel Vaito Escova for their valuable help with the translations during field work. We thank the Education Consortium from the MA course in conservation biology: Universidade Lúrio, Universidade Zambeze, Instituto Superior Politécnico de Manica, Lisbon University, and Parque Nacional da Gorongosa. Finally, we would not have been able to do this work without the valuable and generous support from the Howard Hughes Medical Institute.

Conflicts of Interest: The authors declare no conflict of interest. The funders had no role in the design if the study; in the collection, analyses, or interpretation of data; in the writing of the manuscript, or in the decision to publish the results.

\section{References}

1. Adger, W.N.; Brown, K.; Tompkins, E.L. The political economy of cross-scale networks in resource co-management. Ecol. Soc. 2005, 10, 9. [CrossRef]

2. Elands, B.H.M.; Wiersum, K.F.; Buijs, A.E.; Vierikko, K. Policy interpretations and manifestation of biocultural diversity in urbanized Europe: Conservation of lived biodiversity. Biodivers. Conserv. 2015, 24, 3347-3366. [CrossRef]

3. Maffi, L.; Woodley, E. Biocultural Diversity Conservation, 1st ed.; Earthscan: Washington, DC, USA, $2010 ;$ ISBN 9781844079209.

4. Abesamis, N.P.; Corrigan, C.; Drew, M.; Campbell, S.; Samonte, G. Social Resilience: A Literature Review on Building Resilience into Human Marine Communities in and Around MPA Networks; USAID: Washington, DC, USA, 2006.

5. Gomez-Baggethun, E.; Reyes-García, V.; Oslon, P.; Montes, C. Traditional ecological knowledge and community resilience to environmental extremes: A case study in Donana, SW Spain. Glob. Environ. Chang. 2012, 22, 640-650. [CrossRef]

6. Kaya, H.O.; Seleti, Y.N. African indigenous knowledge systems and relevance of higher education in South Africa. Int. Educ. J. Comp. Perspect. 2013, 12, 30-44.

7. Bhattacharya-Mis, N.; Lamond, J. Socio-economic complexities of flood memory in building resilience: An overview of research. Procedia Econ. Financ. 2014, 18, 111-119. [CrossRef]

8. Berkes, F.; Colding, J.; Folke, C. Rediscovery of Traditional Ecological Knowledge as Adaptive Management. Ecol. Appl. 2000, 10, 1251-1262. [CrossRef]

9. Davidson-Hunt, I.; Berkes, F. Learning as you journey: Anishinaabe perception of social-ecological environments and adaptive learning. Conserv. Ecol. 2003, 8, 1-21. [CrossRef]

10. Parrotta, J.; Yeo-Chang, Y.; Camacho, L.D. Traditional knowledge for sustainable forest management and provision of ecosystem services. Int. J. Biodivers. Sci. Ecosyst. Serv. Manag. 2016, 12, 1-4. [CrossRef]

11. Barthel, S.; Folke, C.; Colding, J. Social-ecological memory in urban gardens-Retaining the capacity for management of ecosystem services. Glob. Environ. Chang. 2010, 20, 255-265. [CrossRef]

12. Puschkarsky, T.; Noriega, E. Working with Indigenous and Local Knowledge Systems for the Conservation and Sustainable Use of Biodiversity and Ecosystem Services; An Analysis of Selected Case Studies from WWF Projects Worldwide as a Contribution to IPBES-2; WWF: Gland, Switzerland, 2013.

13. Hanna, S.; Folke, C.; Mäler, K.-G. Rights to Nature: Ecological, Economic, Cultural and Political Principles of Institutions for the Environment; Island Press: Washington, DC, USA; Covelo, CA, USA, 1996.

14. Ruiz-Mallén, I.; Corbera, E. Community-based conservation and TEK: Implications for social-ecological resilience. Ecol. Soc. 2013, 18, 12. [CrossRef]

15. Agnoletti, M.; Rotherham, I.D. Landscape and biocultural diversity. Biodivers. Conserv. 2015, 24, 3155-3165. [CrossRef]

16. Adger, W.N. Progress in Human Geography Social and ecological resilience: Are they related? Hum. Geogr. 2000, 24, 347-364. [CrossRef]

17. Biacuana, G. Mozambique and Climate Change. 2009. Available online: https://www.saiia.org.za/wp-content/uploads/2009/0 9/dttp_biacuana_climate_change_challenges_for_mozambique_20091026.pdf (accessed on 5 June 2021). 
18. Theron, A.; Barwell, L. Responding to Climate Change in Mozambique-Theme 2: Coastal Planning and Adaptation to Mitigate Climate Change Impacts. 2012. Available online: https:/ /www.academia.edu/24289717/Responding_to_Climate_Change_in_ Mozambique_theme_2_Coastal_planning_and_adaptation_to_mitigate_climate_change_impacts (accessed on 5 June 2021).

19. Parkinson, V. Climate Learning for African Agriculture: The Case of Mozambique; Maputo, Mozambique, 2013. Available online: https://www.nri.org/images/documents/development-programmes/climate_change/publications/WorkingPaper6 Mozambique.pdf (accessed on 5 June 2021).

20. Merci. Climate Change Profile Mozambique. 2015. Available online: https://ees.kuleuven.be/klimos/toolkit/documents/689_ CC_moz.pdf (accessed on 5 June 2021).

21. Ministry of Foreign Affairs of the Netherlands Climate Change Profile Mozambique. 2018. Available online: File://C: /Users/Lau/Downloads/Mozambique.pdf (accessed on 5 June 2021).

22. Winthrop, M.; Kajumba, T.; McIvor, S. Mozambique Country Climate Risk Assessment Report; Irish Aid: Maputo, Mozambique, 2018; $44 \mathrm{p}$.

23. Smith, H.E.; Ryan, C.M.; Vollmer, F.; Woollen, E.; Keane, A.; Fisher, J.A.; Baumer, S.; Grundy, I.M.; Carvalho, M.; Lisboa, S.N.; et al. Impacts of land use intensification on human wellbeing: Evidence from rural Mozambique. Glob. Environ. Chang. 2019, 59, 101976. [CrossRef]

24. Woollen, E.; Ryan, C.M.; Baumert, S.; Vollmer, F.; Grundy, I.; Fisher, J.; Fernando, J.; Luz, A.; Ribeiro, N.; Lisboa, S.N. Charcoal production in the mopane woodlands of Mozambique: What are the trade-offs with other ecosystem services? Philos. Trans. $R$. Soc. B Biol. Sci. 2016, 371, 20150315. [CrossRef]

25. Shaffer, L.J. Human-Environment Interactions on a Coastal Forest-Savanna Mosaic in Southern Mozambique; University of Georgia: Athens, GA, USA, 2009.

26. Management Plan. Park Management Plan Gorongosa National Park. 2016. Available online: https://www.biofund.org.mz/wpcontent/uploads /2015/03/GNP-Park-Mgmt-Plan-DRAFT-8-Feb-2010.pdf (accessed on 5 June 2021).

27. Stalmans, M.E.; Massad, T.J.; Peel, M.J.S.; Tarnita, C.E.; Pringle, M. War-induced collapse and asymmetric recovery of largemammal populations in Gorongosa National Park, Mozambique. PLoS ONE 2019, 14, e0212864. [CrossRef]

28. INGC Synthesis Report. INGC Climate Change Report: Study on the Impact of Climate Change on Disaster Risk in Mozambique; van Logchem, R., Brito, B., Eds.; INGC: Maputo, Mozambique, 2009.

29. INGC Synthesis Report: Disaster Risk Assessments in Mozambique: A Comprehensive Analysis of Country Situation; Pereira, I.J.J.F.; Mavume, A.F.; Afonso, F. (Eds.) INGC: Maputo, Mozambique, 2011.

30. Evans, G.W. Projected Behavioral Impacts of Global Climate Change. Annu. Rev. Psychol 2019, 70, 6-26. [CrossRef]

31. Nash, N.; Whitmarsh, L.; Capstick, S.; Gouveia, V.; De Carvalho, R.; Araújo, R.; Santos, M.; Palakatsela, R. Local climate change cultures: Climate-relevant discursive practices in three emerging economies. Clim. Chang. 2019, 163, 63-82. [CrossRef]

32. Posey, D.A. Cultural and Spiritual Values of Biodiversity. 1999; Available online: https://www.unep.org/resources/publication/ cultural-and-spiritual-values-biodiversity (accessed on 5 June 2021).

33. Gurung, S.M. Human Perception of Mountain Hazards in the Kakani-Kathmandu Area: Experiences from the Middle Mountains of Nepal. Mt. Res. Dev. 1989, 9, 353-364. [CrossRef]

34. Tiwari, K.R.; Awasthi, K.D.; Balla, M.K.; Sitaula, B.K. Local people's perception on Climate Change, its impact and adaptation practices in Himalaya to Terai regions of Nepal. Himal. Res. Pap. Arch. 2010, 1-17. Available online: https:/ / digitalrepository. unm.edu/nsc_research/48/ (accessed on 5 June 2021).

35. Poudel, D.D.; Duex, T.W. Vanishing Springs in Nepalese Mountains Assessment of Water Sources, Farmers' Perceptions, and Climate Change Adaptation. Mt. Res. Dev. 2017, 37, 35-46. [CrossRef]

36. Andrade, G.S.M.; Rhodes, J.R. Protected areas and local communities: An inevitable partnership toward successful conservation strategies? Ecol. Soc. 2012, 17, 1-16. [CrossRef]

37. Pringle, R.M. Upgrading protected areas to conserve wild biodiversity. Nature 2017, 546, 91-99. [CrossRef]

38. Gorongosa National Park a Perfil da Comunidade de Muanandimai. Available online: https://gorongosa.org/ (accessed on 5 June 2021).

39. Gorongosa National Park Perfil da Comunidade de Catemo. Available online: https://gorongosa.org/community / (accessed on 5 June 2021).

40. Bloor, M.; Wood, F. Keywords in Qualitative Methods: A Vocabulary of Research Concepts; SAGE Publications Ltd: London, UK, 2006.

41. Weller, S.C.; Vickers, B.; Russell Bernard, H.; Blackburn, A.M.; Borgatti, S.; Gravlee, C.C.; Johnson, J.C. Open-ended interview questions and saturation. PLoS ONE 2018, 13, e0198606. [CrossRef]

42. Thornton, T.F.; Manasfi, N. Adaptation-Genuine and Spurious: Demystifying Adaptation Processes in Relation to Climate Change. Environ. Soc. Adv. Res. 2010, 1, 132-155. [CrossRef]

43. Motulsky, H.J. Prism 5 Statistics Guide; GraphPad Software Inc.: San Diego, CA, USA, 2007.

44. Reyes-García, V.; Fernández-Llamazares, Á.; Aumeruddy-Thomas, Y.; Benyei, P.; Bussmann, R.W.; Diamond, S.K.; García-delAmo, D.; Guadilla-Sáez, S.; Hanazaki, N.; Kosoy, N.; et al. Recognizing Indigenous Peoples' and local communities' rights and agency in the post-2020 biodiversity agenda. Ambio 2021. [CrossRef]

45. Gandile, A.U.; Tesema, S.M.; Nake, F.M. Biodiversity conservation using the indigenous knowledge system: The priority agenda in the case of Zeyse, Zergula and Ganta communities in Gamo Gofa Zone (Southern Ethiopia). Int. J. Biodivers. Conserv. 2017, 9 , 167-182. [CrossRef] 
46. Fongod, A.G.N.; Ngoh, L.M.; Veranso, M.C. Ethnobotany, indigenous knowledge and unconscious preservation of the environment: An evaluation of indigenous knowledge in South and Southwest Regions of Cameroon. Int. J. Biodivers. Conserv. 2014, 6, 85-99. [CrossRef]

47. Bélair, C.; Ichikawa, K.; Wong, B.Y.L.; Mulongoy, K.L. Promoting Sustainable Use of Biodiversity in Socio-Ecological Production Landscapes; Well-being., B. to the 'Satoyama I. for the benefit of biodiversity and human; Technical Series no. 52; Secretariat of the Convention on Biological Diversity: Montreal, QC, USA, 2010.

48. Renias, N.; Remigious, M. Indigenous Knowledge Systems and the Conservation of Natural Resources in the Shangwe Community in Gokwe District, Zimbabwe. Int. J. Asian Soc. Sci. 2013, 3, 20-28.

49. Löki, V.; Deák, B.; Lukács, A.B.; Molnár, V.A. Biodiversity potential of burial places-A review on the flora and fauna of cemeteries and churchyards. Glob. Ecol. Conserv. 2019, 18, e00614. [CrossRef]

50. Matos, E.A.C. de Universidade Federal do Rio Grande do Sul Instituto de Geociências Programa de Pós-Graduação em Geografia a Nova Abordagem de Gestão de Áreas de Conservação e suas Implicações Socioespaciais: O caso de Chimanimani no Centro de Moçambique; Universidade Federal do Rio Grande do Sul: Porto Alegre, Brazil, 2011.

51. Wilson, J.; Primack, R. Conservation Biology in Sub-Saharan Africa; Open Book Publishers: Cambridge, UK, 2019; ISBN 9781783747504 .

52. Ruiz-Mallén, I.; Barraza, L.; Bodenhorn, B.; Reyes-García, V. School and local environmental knowledge, what are the links? A case study among indigenous adolescents in Oaxaca, Mexico. Int. Res. Geogr. Environ. Educ. 2009, 18, 82-96. [CrossRef]

53. Wilson, G.A.; Kelly, C.L.; Briassoulis, H.; Ferrara, A.; Quaranta, G.; Salvia, R.; Detsis, V.; Curfs, M.; Cerda, A.; El-Aich, A.; et al. Social Memory and the Resilience of Communities Affected by Land Degradation. L. Degrad. Dev. 2017, 28, 383-400. [CrossRef]

54. Recha, C.W.; Makokha, G.L.; Shisanya, C.A. Climate variability and causes: From the perspective of the Tharaka people of eastern Kenya. Geosci. Lett. 2017, 4, 2-8. [CrossRef]

55. Ombati, M. Rainmaking rituals: Song and dance for climate change in the making of livelihoods in Africa. Int. J. Mod. Anthropol. 2017, 10, 74-96. [CrossRef]

56. Babane, M.T.; Chauke, M.T. The Preservation of Xitsonga Culture through Rainmaking Ritual: An Interpretative Approach. Stud. Tribes Tribals 2015, 13, 108-114. [CrossRef]

57. Agrawal, A. The Role of Local Institutions in Adaptation to Climate Change; Word Bank: Washington, DC, USA, 2008.

58. Gautam, Y. Seasonal Migration and Livelihood Resilience in the Face of Climate Change in Nepal. Mt. Res. Dev. 2017, 37, 436-445. [CrossRef]

59. Conceição, A.; Tedim, F. Análise da dinâmica e bem-estar das Comunidades no Parque Nacional do Limpopo: Uma abordagem socio-ecológica para a conservação da natureza. As Dimensões e a Responsabilidade Social da Geografia: XI Congresso da Geografia Portuguesa: Livro de Atas. 2017, pp. 1-7. Available online: https:/ / repositorio-aberto.up.pt/handle/10216/109951 (accessed on 5 June 2021).

60. Nykvist, B.; von Heland, J. Social-ecological memory as a source of general and specified resilience. Ecol. Soc. 2014, 19, 1-13. [CrossRef]

61. Marshall, N.A.; Fenton, D.M.; Marshall, P.A.; Sutton, S.G. How resource dependency can influence social resilience within a primary resource industry. Rural Sociol. 2007, 72, 359-390. [CrossRef]

62. Marshall, N.A. Understanding social resilience to climate variability in primary enterprises and industries. Glob. Environ. Chang. 2010, 20, 36-43. [CrossRef]

63. Ruiz-Mallén, I.; Schunko, C.; Corbera, E.; Rös, M.; Reyes-García, V. Meanings, drivers, and motivations for community-based conservation in Latin America. Ecol. Soc. 2015, 20, 1-14. [CrossRef] 